\title{
VLDL Apolipoprotein B Determination in Blood Serum Following Precipitation of LDL with Polyvinylsulphate
}

\author{
By H. Schriewer, W. Nolte and G. Assmann \\ Institut für Klinische Chemie und Laboratoriumsmedizin (Zentrallaboratorium) \\ Medizinische Einrichtungen der Westfälischen Wilhelms-Universität Münster
}

(Received October 10, 1984/January 31, 1985)

Summary: A method is described for the determination of VLDL apolipoprotein B by radial immunodiffusion (RID) in serum supernatants following precipitation of LDL with polyvinylsulphate. The measurement of VLDL apolipoprotein B is based on the incubation of the polyvinylsulphate supernatant with triglyceride lipase (330 kU/l end concentration) for $12-24$ hours at $37^{\circ} \mathrm{C}$. A good measure of agreement was found for the corresponding VLDL apolipoprotein $\mathrm{B}$ values measured by RID in the polyvinylsulphate supernatants (y) and VLDL apolipoprotein B values calculated as tetramethylurea-insoluble protein in the $\mathrm{d}<1.006 \mathrm{~kg} / \mathrm{l}$ serum fraction $(x)(r=0.88, y=0.96 x+0.004, n=54)$. Within the tested range of $1.2 \mathrm{mmol} / 1$ to 6.7 $\mathrm{mmol} / \mathrm{l}$ triglycerides, the concentration of apolipoprotein B measured in the polyvinylsulphate supernatant showed a linear relationship. Correlation analysis of VLDL apolipoprotein B values and serum triglycerides and VLDL cholesterol, respectively, showed a good correlation $(r=0.77$ and $r=0.75$, respectively, $\mathrm{n}=$ 54). In the determination of VLDL apolipoprotein $B$ measured in polyvinylsulphate supernatant, a variation coefficient of $4.3 \%(\overline{\mathrm{x}}=10.1 \mathrm{mmol} / \mathrm{l}, \mathrm{n}=20)$ was found in relation to the precision in the series, and a variation coefficient of $11.4 \%(\overline{\mathrm{x}}=5.3 \mathrm{mmol} / \mathrm{l}, \mathrm{n}=15)$ in relation to day to day precision.

\section{VLDL Apolipoprotein B Bestimmung im Blutserum nach Präzipitation von LDL mit Polyvinylsulfat}

Zusammenfassung: Es wird eine Methode zur Bestimmung von VLDL Apolipoprotein B mittels radialer Immundiffusion (RID) im Fällungsüberstand nach vorheriger Präzipitation der LDL mit Polyvinylsulfat beschrieben. Die Richtigkeit der Messung von VLDL Apolipoprotein B gründet sich auf die Inkubation der Polyvinylsulfat-Fällungsüberstände mit Triglyceridlipase ( $330 \mathrm{kU} / 1$ Endkonzentration) für $12-24$ Stunden bei $37^{\circ} \mathrm{C}$. Es wurde eine gute Übereinstimmung der VLDL Apolipoprotein B-Wertepaare gefunden, die mittels RID im Polyvinylsulfat-Überstand (y) gemessen und als Tetramethylharnstoff unlösliches Protein in der $\mathrm{d}<1,006 \mathrm{~kg} / \mathrm{l}$ Serumfraktion ( $\mathrm{x}$ ) ermittelt wurden $(\mathrm{r}=0,88, \mathrm{y}=0,96 \mathrm{x}+0,004, \mathrm{n}=54)$. Innerhalb des untersuchten Bereichs von $1,2 \mathrm{mmol} / \mathrm{l}$ bis $6,7 \mathrm{mmol} / 1$ Triglyceriden waren die VLDL Apolipoprotein B-Werte im Fällungsüberstand linear. Die Korrelationsanalyse der im Polyvinylsulfat-Fällungsüberstand gemessenen VLDL Apolipoprotein B-Werte und der Triglycerid- bzw. der VLDL Cholesterinwerte im Serum ergab eine gute Korrelation der jeweiligen Wertepaare $(r=0,77$, bzw. $r=0,75 ; n=54)$. Der Variationskoeffizient der VLĐL Apolipoprotein B-Bestimmung' nach Polyvinylsulfat-Fällung hinsichtlich der Präzision in der Serie betrug 4,3\% $(\overline{\mathrm{x}}=10,1 \mathrm{mmol} / \mathrm{l}, \mathrm{n}=20)$ und hinșichtlich der Präzision von Tag zu Tag $11,4 \%(\overline{\mathrm{x}}=5,3$ $\mathrm{mmol} / \mathrm{l}, \mathrm{n}=15)$.

\section{Introduction}

Apolipoprotein B represents the functional entity of several lipoproteins, especially of very low density lipoproteins (VLDL) and low density lipoproteins
(LDL). Normally, more than $90 \%$ of total apolipoprotein B is transported in LDL, whereas approximately $4-5 \%$ of total apolipoprotein B is found in VLDL (1). LDL apolipoprotein B represents 
the marker for the recognition of LDL by peripheral and hepatic receptors (2). It is well known that increased concentrations of apolipoprotein B-containing lipoproteins are associated with premature atherosclerosis $(3,4)$. Thus, quantification of apolipoprotein B is possibly relevant for clinical and epidemiological purposes. The determination of apolipoprotein B in LDL or VLDL usually implies a time consuming separation of lipoproteins. Furthermore, the accurate measurement of apolipoproteins has been hampered by technical problems (5).

According to studies of Franceschini et al. (6), increased concentrations of apolipoprotein B in VLDL are associated with peripheral vascular disease. Therefore, the determination of VLDL apolipoprotein B may be of special clinical and epidemiological significance. Recently a commercial test has been developed for the analysis of LDL cholesterol following selective precipitation of LDL with polyvinylsulphate (7). Using this procedure we have developed a method for the determination of VLDL apolipoprotein B using radial immunodiffusion.

\section{Materials and Methods}

\section{Sample material}

As test material we used fresh serum from the test series "Prospective epidemiological study in company employees in Westfalia" (8).

\section{Precipitation of $L D L$ with polyvinylsulphate}

Precipitation of LDL with polyvinylsulphate was performed as previously described (7) using the Boehringer Mannheim test, catalogue no. 726290 (Boehringer Mannheim, FRG). For the LDL precipitation $200 \mu$ l serum were mixed in an incubation tube (Sarstedt no. 52690) with $100 \mu$ precipitation reagent, left at room temperature for 15 minutes and centrifuged in an Eppendorf centrifuge 3200 for $2 \times 2$ minutes.

\section{Determination of VLDL cholesterol}

In the supernatant obtained by polyvinylsulphate precipitation cholesterol was determined enzymatically using the cholesterol oxidase/4-aminophenazone phenol method (Boehringer Mannheim monotest cholesterol, cat. no. 237574). HDL cholesterol was determined by measuring cholesterol in the supernatant (Boehringer Mannheim monotest cholesterol high performance, cat. no. 737574) following precipitation of apolipoprotein B-containing lipoproteins in serum using phosphotungstate/ $\mathrm{MgCl}_{2}$ (9). VLDL cholesterol was calculated from the difference between cholesterol in the polyvinylsulphate supernatant and HDL cholesterol.

Determination of apolipoprotein $B$ by radial immunodiffusion (RID)

Supernatant $(100 \mu \mathrm{l})$ obtained by polyvinylsulphate precipitation of serum was mixed with $50 \mu$ triglyceride lipase (1 MU/1, Calbiochem. Behring Corp., La Jolla Ca, 92037, order no. 437611). The enzyme was solubilised in saline containing $0.02 \mathrm{~mol} / \mathrm{l}$ Na-phosphate buffer pH 8.0, according to Kostner (personal communication). The mixture was incubated at $37^{\circ} \mathrm{C}$ for $12-24 \mathrm{~h}$ and centrifuged at approximately $1000 \mathrm{~g}$. RID was performed according to Mancini et al. (10). Anti-apo-B (40 $\mu$ ) (Immunoscientific Anti Apo B, Immuno AG, Vienna, order no. 483.40005 ) was mixed with $20 \mathrm{ml}$ of $10 \mathrm{~g} / \mathrm{l}$ solution of agarose in Tris-barbital-lactate buffer $\mathrm{pH} 8.6(0.045 \mathrm{~mol} / 1 \mathrm{Tris}, 0.015$ $\mathrm{mol} / \mathrm{l}$ barbituric acid, $1.9 \mathrm{mmol} / \mathrm{l} \mathrm{Na}$ azide, $0.21 \mathrm{mmol} / \mathrm{l} \mathrm{Ca}$ lactate). The volume of the lipase-treated sample was $10 \mu \mathrm{l}$. As standard we used RID Reference Standard Apoproteins human (Immuno Comp. D-6900 Heidelberg, order no. 4910005). Standard solutions were diluted with $0.15 \mathrm{~mol} / 1 \mathrm{NaCl} 1: 2,1: 4,1: 8$, $1: 16,1: 32,1: 64$. The standard was not treated with lipase. Incubation time was 4 days at room temperature. The diameter of the precipitation rings obtained were measured following staining with Servablue R (Serva, 6900 Heidelberg, FRG).

\section{Preparative isolation of VLDL by ultracentrifugation}

Preparative isolation of VLDL by ultracentrifugation was performed as previously described (11).

Determination of tetramethylurea-insoluble protein in VLDL (d $<1.006 \mathrm{~kg} / \mathrm{l}$ serum fraction)

Determination of the tetramethylurea-insoluble protein in VLDL ( $\mathrm{d}<1.006 \mathrm{~kg} / \mathrm{l}$ serum fraction) was performed as described by Kane et al. (12).

\section{Determination of triglycerides}

Triglycerides were determined fully enzymatically using the enzymatic triglyceride assay after enzymatic hydrolysis (Boehringer Mannheim test combination triglyceride vollenzymatisch UV-Test, cat. no. 240052).

\section{Results}

Influence of lipase on apolipoprotein B determination in the polyvinylsulphate superriatant

The incubation of the supernatant following precipitation of sera with polyvinylsulphate using triglyceride lipase caused an increase in the diameter of the precipitation rings. As shown in figure 1, the calculated apolipoprotein $B$ values in the supernatant rose on average by $78 \%$ in comparison to untreated samples.

\section{Comparison of apolipoprotein $B$ in polyvinylsulphate supernatant and tetramethylurea-insoluble protein in the $d<1.006 \mathrm{~kg} / \mathrm{l}$.serum fraction}

Apolipoprotein B values were measured in the polyvinylsulphate supernatant of serum, and they were calculated as the VLDL tetramethylurea-insoluble protein in normo- and hypertriglyceridaemic sera. Both methods gave similar values $(r \cdot=0.76, y=$ $1.1 \mathrm{x}-0.012, \mathrm{n}=18)$. As secondary standard we used the polyvinylsulphate supernatant of a pool serum. The apolipoprotein B concentration of this secondary standard was determined as the VLDL 


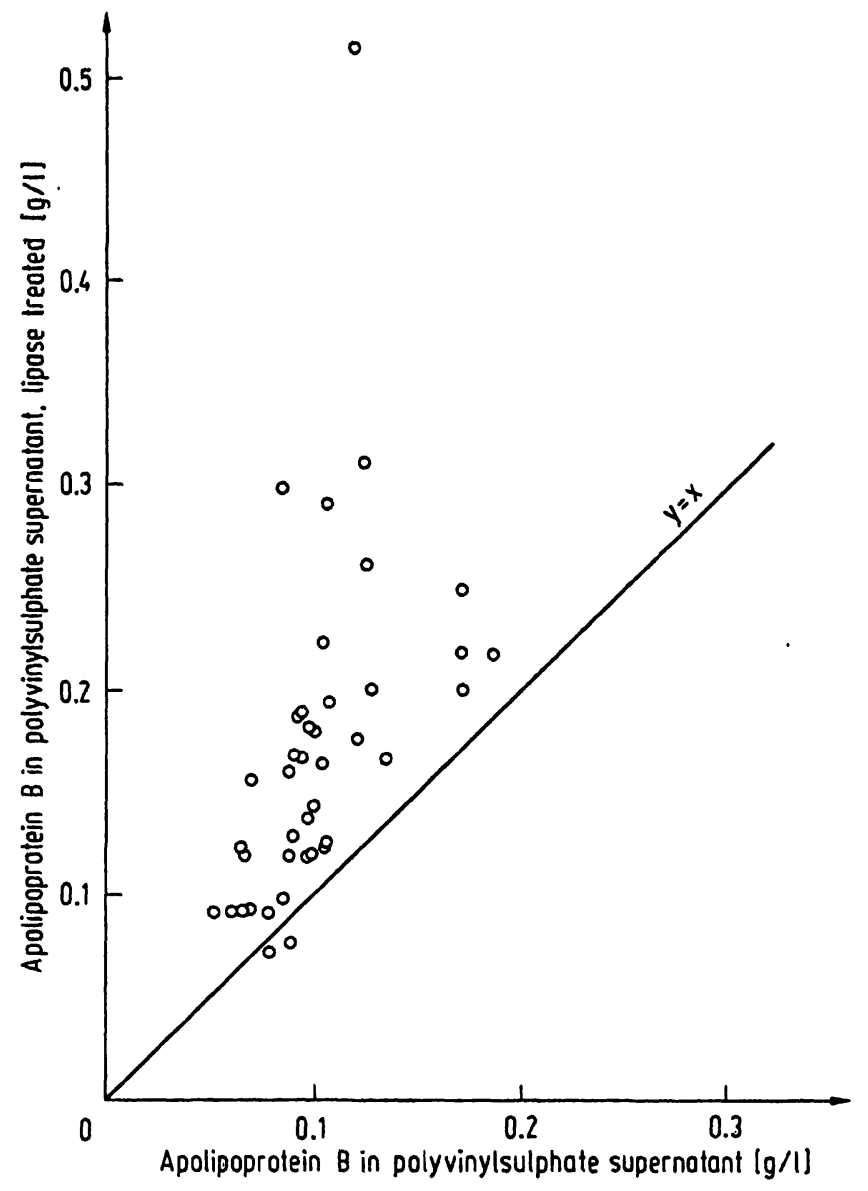

Fig. 1. Influence of lipase treatment $(330 \mathrm{kU} / 1$ end concentration) of the polyvinylsulphate supernatant on the concentration of VLDL apolipoprotein B values measured by RID.

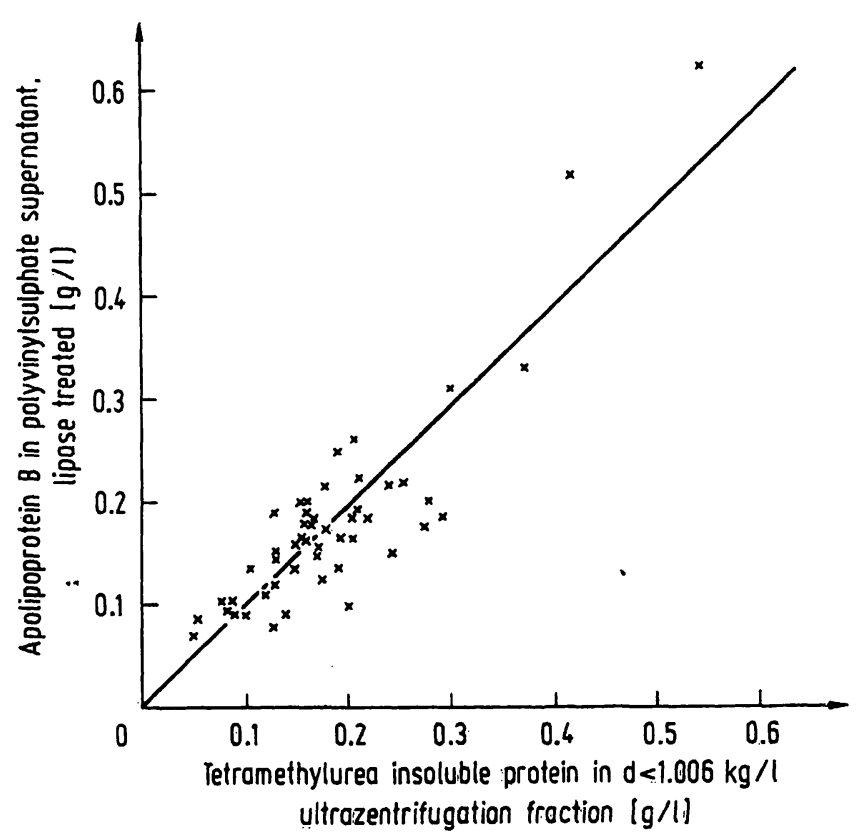

Fig. 2. Regression analysis of VLDL apolipoprotein B values calculated as the VLDL tetramethylurea insoluble protein $(x)$ versus apolipoprotein values measured in the lipase treated polyvinylsulphate supernatant of sera $(y)$; $r=0.88, y=0.96 x+0.004, n=54$. tetramethylurea-insoluble protein. Using the RID Reference Standard (Immuno Comp.) for standardisation, similar results were obtained $(r=0.88, y=$ $0.96 x+0.004, n=54$ ) (fig. 2). The applicability of the RID Reference Standard (Immuno Comp.) was tested by recalculation of the apolipoprotein $B$ value using the secondary standard (see above) (tab. 1). Regression analysis of the apolipoprotein B values in the polyvinylsulphate supernatant and apo: lipoprotein $B$ values in the $\mathrm{d}<1.006 \mathrm{~kg} / \mathrm{l}$ serum fraction treated with triglyceride lipase, both measured by RID, showed different results. On the average apolipoprotein B values in the polyvinylsulphate supernatant were $18.5 \%$ higher than apolipoprotein $B$ values in the $d<1.006 \mathrm{~kg} / \mathrm{l}$ serum fraction $(r=0.48, y=1.5 x-0.04, n=23)$. However, this difference was not observed when albumin was added to the $d<1.006 \mathrm{~kg} / \mathrm{l}$ fraction (40 $\mathrm{g} / \mathrm{l}$ end concentration) before incubation with triglyceride lipase.

Tab. 1. Recalculation of the apolipoprotein B concentration ( $\mathrm{g} / \mathrm{l}$ ) in RID Reference Standard (Immuno Comp.). A polyvinylsulphate supernatant of a pool serum was used as standard, in which the apolipoprotein B concentration was calculated as the VLDL tetramethylurea-insoluble protein.

\begin{tabular}{lll}
\hline $\begin{array}{l}\text { Reference } \\
\text { standard } \\
\text { dilutions }\end{array}$ & $\begin{array}{l}\text { Concentration } \\
\text { expected }\end{array}$ & $\begin{array}{l}\text { Concentration } \\
\text { recalculated from the } \\
\text { polyvinylsulphate } \\
\text { supernatant of a } \\
\text { pool serum }\end{array}$ \\
\hline $1 / 8$ & 0.0904 & 0.094 \\
$1 / 16$ & 0.0452 & 0.046 \\
$1 / 32$ & 0.0226 & 0.019 \\
\hline
\end{tabular}

Comparison of VLDL apolipoprotein B with triglycerides and VLDL cholesterol

There was a good correlation of the VLDL apolipoprotein B values with triglycerides and VLDL cholesterol, irrespective of whether the apolipoprotein B values were calculated as VLDL tetramethylurea-insoluble protein or measured in the polyvinylsulphate supernatant (tab. 2).

Tab.2. Coefficients of the correlation analysis of VLDL apolipoprotein B versus VLDL cholesterol and triglycerides, respectively.

\begin{tabular}{lll}
\hline & $\begin{array}{l}\text { VLDL tetra- } \\
\text { methylurea- } \\
\text { insoluble } \\
\text { protein }\end{array}$ & $\begin{array}{l}\text { Apolipoprotein B } \\
\text { in polyvinylsulphatc } \\
\text { supernatant }\end{array}$ \\
\hline VLDL cholesterol & $\mathrm{r}=0.74$ & $\mathrm{r}=0.75$ \\
& $(\mathrm{n}=54)$ & $\begin{array}{l}(\mathrm{n}=54) \\
\text { Triglycerides }\end{array}$ \\
& $\mathrm{r}=0.77$ & $\mathrm{r}=0.77$ \\
& $(\mathrm{n}=54)$ & $(\mathrm{n}=54)$ \\
\hline
\end{tabular}




\section{Linearity of apolipoprotein $B$ values}

Linearity of apolipoprotein B values using polyvinylsulphate precipitation was studied using different mixtures of two sera with considerably different triglyceride values (fig. 3). It was found that the apolipoprotein $B$ value measured in the polyvinylsulphate supernatant was proportional to the ratio of components below a triglyceride concentration of $6.7 \mathrm{mmol} / \mathrm{l}$, but it deviated at higher concentrations of triglyceride.

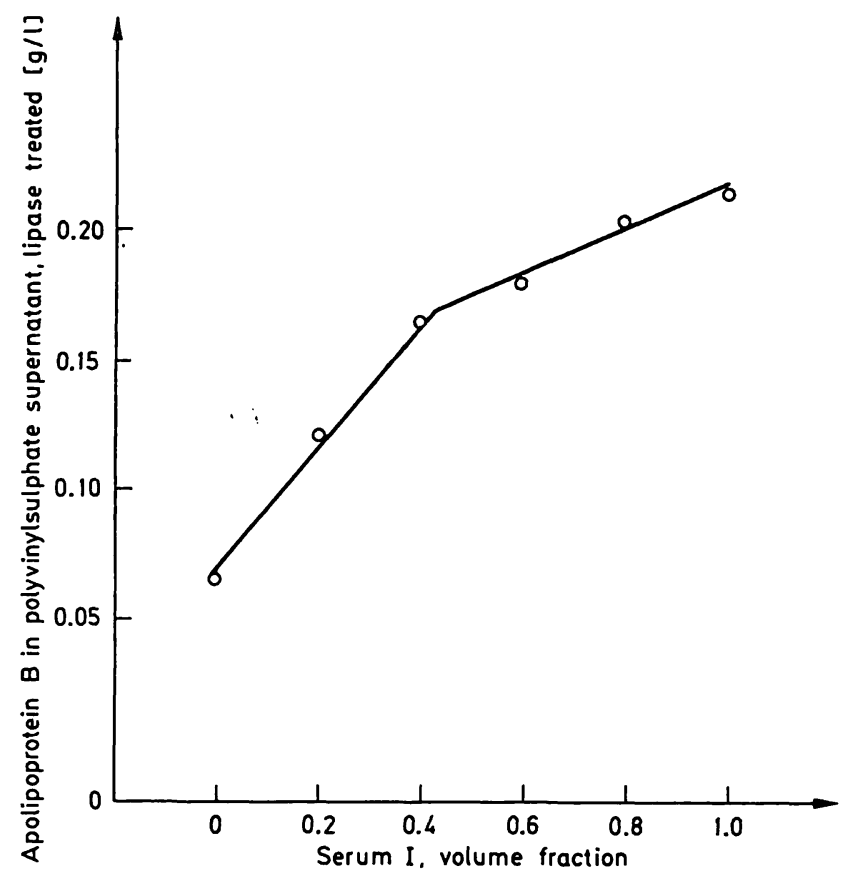

Fig. 3. Apolipoprotein B concentration in lipase treated polyvinylsulphate supernatant as a function of the volume ratio when two sera with high (serum I, $15.0 \mathrm{mmol} / \mathrm{l}$ ) and low $(1.22 \mathrm{mmol} / \mathrm{l})$ triglyceride concentrations were mixed.

Precision of the apolipoprotein $B$ determination in the polyvinylsulphate supernatant

With regard to the precision in the series a variation coefficient of $4.3 \%(n=20)$ was found. Day to day precision $(11.4 \%(n=15))$ was tested with samples of frozen pool serum which had been stored at $-30^{\circ} \mathrm{C}$.

\section{Discussion}

In the present study apolipoprotein B was determined in the supernatant obtained after precipitation of VLDL with polyvinylsulphate. In a previous study we showed that polyvinylsulphate precipitation was selective for LDL and $\mathrm{Lp}(\mathrm{a})$ with only negligible coprecipitation of VLDL or HDL (7). Regression analysis of the VLDL cholesterol values calculated in the polyvinylsulphate supernatant and calculated by ultracentrifugation showed a good correspondence of results (7). It may be assumed that VLDL apolipoprotein B behaves exactly like cholesterol in the polyvinylsulphate precipitation procedure. As our results show, VLDL apolipoprotein B measured in the polyvinylsulphate supernatant agreed on average excellently with tetramethylurea'-insoluble proteins measured in the $\mathrm{d}<1.006 \mathrm{~kg} / \mathrm{l}$ serum fraction. The determination of the VLDL tetramethylurea-insoluble protein is generally considered as the reference method for the determination of VLDL apolipoprotein $B(12,13)$. However, the determination of the VLDL tetramethylurea-insoluble protein is an elaborate and time consuming method and is not sufficiently precise because apolipoprotein B is calculated as the difference between total protein and tetramethylurea-soluble protein. Possibly the large scatter obtained in the regression analysis of our results may be explained by the imprecision of the reference method used. In contrast to the reference method our results showed an improved precision using the direct measurement of apolipoprotein B in the polyvinylsulphate supernatant.

Compared with total apolipoprotein $\vec{B}$ in plasma, the apolipoprotein B concentration in VLDL is low $(4-5 \%)$. Therefore, for the determination of VLDL apolipoprotein B a sensitive method is necessary. In our study the sensitivity of the RID was enhanced by the reduction of antibody concentration to $0.2 \%$. After staining with Coomassie blue the ring diameters could be clearly visualised. The lower limit of detection was $23 \mathrm{mg} / \mathrm{l}$ VLDL apolipoprotein B.

According to our results, only lipase-treated samples yielded correct VLDL apolipoprotein B values in the polyvinylsulphate supernatant. Compared with untreated samples, lipase treatment resulted in a significant increase of the ring diameters, especially in samples obtained from hypertriglyceridaemic individuals. The effect of lipase treatment on the ring diameter may be based on a change of immunoreactivity. Similar observations were previously made by Schonfeld et al. (14). These authors found an increase in the apparent apolipoprotein B content of VLDL treated by lipoprotein lipase only in those assays that contained anti-LDL antisera but not in those assays that contained anti-VLDL antisera. $\mathrm{Ob}$ viously, the anti-LDL antibodies also used in our experiments do not recognise all antigenic sites of the apolipoprotein B component in VLDL. However, lipase treatment as well as treatment with lipoprotein lipase may change the immunoreactivity, either by removing lipids and apolipoproteins during lipolysis, so that masked areas of apolipoprotein $\mathrm{B}$ become uncovered, or by converting larger VLDL particles 
into smaller ones so that apolipoprotein B on the surface of the particles is altered to adjust to the new surface geometry and composition of the particles. It must be considered that triglyceride lipase possibly produces side effects; for example, it may cleave lecithin into lysolecithin (phospholipase activity) which is known to be an effective detergent.

In contrast to the significant enhancement of the immunoreactivity using the polyvinylsulphate supernatant, the enhancement of the immunoreactivity in the $\mathrm{d}<1.006 \mathrm{~kg} / \mathrm{l}$ serum fraction following lipase treatment is very small. Since the addition of albumin to the VLDL fraction, which is obviously poor in albumin, resulted in an increase in

\section{References}

1. Thompson, G. R., Birnbaumer, M. E., Levy, R. J. \& Gotto jr, A. M. (1976) Atherosclerosis 24, 107-118.

2. Goldstein, J. \& Brown, M. (1974) J. Biol. Chem. 249, $5153-5162$.

3. Gofmann, J. W., Young, W. \& Tandy, R. (1966) Circulation 34, 679-697.

4. Avogaro, P., Bittolo Bon, G., Cazzalato, G., Quinci, G. B. \& Belussi, F. (1978) Artery 4, 385-394.

5. Rosseneu, M., Vercaemst, R., Steinberg, K. K. \& Cooper, G. R. (1983) Clin. Chem. 29, 427-433.

6. Franceschini, G., Bondioli, A., Mantero, M., Sirtori, M., Tattoni, G., Biasi, G. \& Sirtori, C. R. (1982) Arteriosclerosis 2, 74-80.

7. Assmann, G., Jabs, H.-U., Kohnert, U., Nolte, W. \& Schriewer, H. (1984) Clin. Chim. Acta 140, 77-83. immunoreactivity it can be concluded that free fatty acids generated by the lipase resulted in an inhibition of the immunoreactivity. On the other hand, the polyvinylsulphate supernatant contains all the plasma albumin which binds the free fatty acids generated by the lipase.

In spite of the heterogeneous composition of VLDL in hypertriglyceridaemic sera, the linearity of our method extended to a triglyceride concentration of approximately $6.7 \mathrm{mmol} / \mathrm{l}$. Also, in hypertriglyceridaemic sera, VLDL apolipoprotein B values in polyvinylsulphate supernatant were in good agreement with the VLDL apolipoprotein B values measured by the reference method.

8. Assmann, G., Oberwittler, W., Schulte, H., Schriewer, H., Funke, H., Epping, P. H. \& Hauss, W. H. (1980) Internist $21,446-459$.

9. Assmann, G., Schriewer, H., Schmitz, G. \& Hägele, E.-O. (1983) Clin. Chem. 29, 2026-2030.

10. Mancini, G., Carbonara, A. O. \& Heremans, J. F. (1965) Int. J. Immunochem. 2, 235-254.

11. Schriewer, H., Kohnert, U. \& Assmann, G. (1984) J. Clin. Chem. Clin. Biochem. 22, 35-40.

12. Kane, J. P., Sata, T., Hamilton, R. L. \& Havel, R. J. (1975) J. Clin. Invest. 56, 1622-1634.

13. Holmquist, L. \& Carlson, K. (1977) Biochim. Biophys. Acta 493, 400-409.

14. Schonfeld, G., Patsch, W., Pfleger, B., Witztum, J. L. \& Weideman, S. W. (1979) J. Clin. Invest. 64, 1288-1297.
Professor Dr. H. Schriewer Institut für Klinische Chemie und Laboratoriumsmedizin Medizinische Einrichtungen der Westfälischen Wilhelms-Universität Albert-Schweitzer-Straße 33 D-4400 Münster 
